\title{
Effectiveness of Hyperthermia on Cancer Stem Cells
}

\author{
KEN OHNISHI
}

Department of Biology, Center for Humanity and Sciences, Ibaraki Prefectural University of Health Sciences, Inashiki-gun, Ibaraki 300-0394, Japan

\begin{abstract}
Cancer stem cells (CSCs) or tumor-initiating cells (TICs) have been identified in a variety of cancers and are defined as a small population of cancer cells that have stem cell-like phenotypes. CSCs are resistant to current chemotherapy and radiotherapy and have high ability of tumorigenesis. It is likely that CSCs contribute to cancer metastases and tumor recurrence, which cause a poor prognosis. Thus, targeting strategy of CSCs is extremely important for advancement of cancer therapies. However, CSC itself is not well understood. This review refers to key points to be noticed in CSC research and considers effectiveness of hyperthermia for CSC-targeting. It has been reported that heating has an inhibitory influence on some extra- and intra-cellular factors that are related to the survival of CSCs. In this review, the potentiality of hyperthermia for CSC-targeted cancer therapy is discussed with relation to those survival factors.
\end{abstract}

Key Words: hyperthermia, cancer stem cell, niche, hypoxia, spheroid

\section{1. がん幹細胞とは何か}

がん幹細胞は 1997 年に白血病で同定され，その後 2003 年に乳がん， 2004 年に脳腫瘍， 2005 年に食 道がん，肝臓がんなど固形がんにおいてもそれぞれ同定された。2006 年の米国がん学会（AACR）に おいて, がん幹細胞は腫瘍内に存在し，自己袙製能と腫瘍を構成するさまざまな系統のがん細胞を生み 出す能力（多分化能）を併せ持つ細胞と定義された（Fig. 1) ${ }^{1)}$. がん幹細胞の発生機序については現在 以下の二つの仮説が提示されている21.

(1) 自己複製能を有する正常組織細胞に強力な形質転換能力を持つ遺伝子変異が導入され，がん幹細胞 に変化する。

(2)分化前の前駆細胞に過形成あるいは異形成が起こり, その後脱分化が生じ, がん幹細胞が生まれる. さらに最終的に分化したがん細胞にも脱分化が生じ，がん幹細胞ができるとも言われている，実際に がん幹細胞が生体内で発生する過程をリアルタイムで観察することは困難なため, これらの仮説はまだ 実証されていない.

\section{2. がん幹細胞研究の注意すべき点}

\section{2-1. がん幹細胞の形質維持}

がん幹細胞を実験材料として取り扱う上で注意すべき点は腫瘍組織内微小環境（ニッチ）特有のがん

Received 7 April, 2017, Accepted 28 June, 2017. *Corresponding author: Tel, +81-29-840-2157; Fax, +81-29-840-2316; 
幹細胞の形質発現を細胞培養系でどう維持するかという点である。ニッチとはがん幹細胞を形成, 維持 する環境である。生体内のがん幹細胞の形質発現維持には低酸素, 低栄養, 低 $\mathrm{pH}$ などの腫瘍組織内の 微小環境や近傍の細胞とのコミュニケーションが媣く関わっている。特に低酸素環境では, HIF-1 $\alpha$ の 安定化が，がん幹細胞マーカー発現にとって重要である ${ }^{3,4)}$. また組織を形づくる3 次元立体構造その ものが形質発現に大きく影響を与えることも正常細胞で知られている5 ${ }^{5}$. 従って, 一般的に広く行われ ている細胞の単層培養では生体内の微小環境と異なり,がん幹細胞の形質は容易に変化すると思われる. 本来のがん幹細胞の形質を維持しつつ, 培養系の実験を進めて行くには細心の注意が必要である.

現在，がん幹細胞を扱う場合，できるだけがん幹細胞の形質を維持するように培養条件が工夫されて いる，例えば，脳腫瘍のがん幹細胞を扱う場合，腫瘍を分散させた後，幹細胞の自己複製能を維持する ためにEGF, bFGF, B27 などの増殖因子を添加した Neurobasal 培地を用い, 非接着性のプレートで培 養する場合が多い。しかし，このような条件下でがん幹細胞の形質が充分に維持されているかは疑問で ある。通常の細胞培養環境では, 腫瘍組織内の様々な微小環境は充分に再現されないことを強く意識す る必要がある。またその形質が維持されたとしても，有効な培養期間についての詳細はまだ明らかにさ れていない，理想的には生体から摘出直後の腫瘍からがん幹細胞を回収し，がん幹細胞形質が維持され ている間に実験を完了するのが最善であるが, 後日再実験や追加実験が必要になった場合, 一旦培養系 に移してしまった細胞を再び実験に用いて問題はないであろうか。このような懸念から，摘出した腫瘍 を用いずに株化したがん細胞からがん幹細胞マーカーを目安に細胞をソーティングし，それらをがん幹 細胞と見なして実験に用いている研究も多い。しかしながら, マーカー陽性だけを目安に回収した細胞 を生体内に存在するがん幹細胞と果たして同一視しても良いのだろうか. マーカー陰性を示す細胞でも がん幹細胞特有の性質を示すとの報告も少なくなく, がん幹細胞マーカーだけで判定された細胞は真の がん幹細胞と一応区別する必要がある。

\section{2-2. がん幹細胞の判定方法}

それではどんな細胞をがん幹細胞として同定すべきだろうか．前述したがん幹細胞の特性を全て調べ ることは大変困難である，検定する特性を絞る必要がある。幹細胞が持つ本来の重要なはたらきは組織 を形成維持することにある，がん幹細胞においても，腫瘍組織の形成維持に寄与する対称分裂能と非対 称分裂能（Fig. 1）は重要な特性と思われ, 最も信頼できるがん幹細胞の判定基準の一つである. 対称

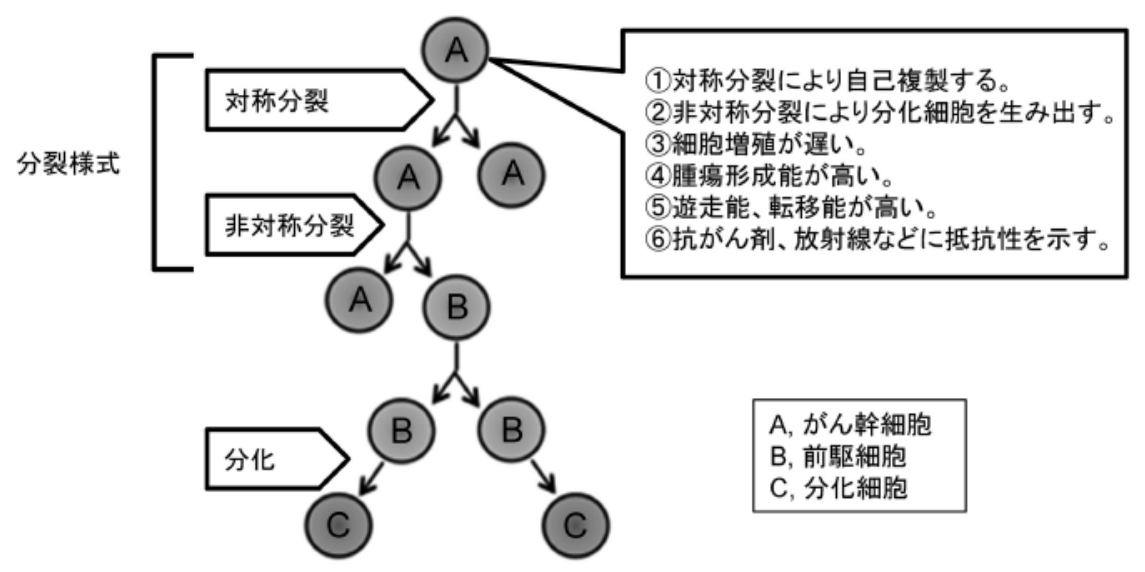

Fig. 1. がん幹細胞の性質. 
分裂能と非対称分裂能を確かめるには，一つの細胞が分裂を完了し，二つの娘細胞になった時点でそれ ぞれの細胞を単離し, 遺伝子発現やタンパク質発現を感度の高い分析機器を用いてシングルセル解析す れば良い，両方の娘細胞が共にがん幹細胞特有の遺伝子発現あるいはタンパク質発現を示せば，分裂前 の細胞は対称分裂能を保持していたことになる。これとは異なり, 一方の細胞はがん幹細胞特有の遺伝 子あるいはタンパク質発現を示し，もう一方の細胞はがん細胞特有の遺伝子あるいはタンパク質発現を 示す場合には，非対称分裂能を保持していたことになる。なお，がん幹細胞が対称分裂するか非対称分 裂能するかは細胞内外の要因によって決まる。患者の腫瘍から回収したCD133 陽性グリオーマ細胞を 用いた実験では，大半の細胞が非対称分裂するが， EGF と bFGF を培地に添加すると，それらを添加 しない場合に比べ対称分裂をするグリオーマ幹細胞の割合が多くなることが示されている゙ 胞の分化が抑えられて自己複製が優先されるものと思われる。ささらに，このような対称分裂能と非対称 分裂能を持つ細胞に xenograft での高い腫瘍形成能が認められた場合には, がん幹細胞と同定する確固 たる証拠となる。

近年，腫瘍は異なる性質のがん細胞からなるへテロな細胞集団であることが明らかにされ7,8)，がん 治療の難しさの一つはこのへテロ性に起因すると言われている，個々のがん細胞のへテロ性あるいはご く少数の細胞からなる亜集団間のへテロ性を調べる場合，シングルセル解析の有用性は高い ${ }^{9,10)}$ ．たた シングルセル解析法は新しく開発された技術を利用しているため, ソフトとハードの両面においてまだ 一般的に広く普及していない．参考のために細胞の単離方法と細胞を単離した後にどのような解析が可 能かを Table I にまとめた，細胞の単離方法は解析目的に合わせ選択する必要がある。なお，DNA チッ プを用いたシングルセル網羅的遺伝子発現解析システムについては, 日立製作所が約 2,000 個の遺伝子 発現を解析できる小型チップを開発したと 2016 年に発表している ${ }^{11)}$. 今後, その実用化が待たれる.

Table I. シングルセルの単離法と解析法

\begin{tabular}{|c|c|c|c|c|}
\hline 単離法 & 装置 & $\begin{array}{l}\text { 一度に単離可 } \\
\text { 能な細胞数 }\end{array}$ & 選択基準 & 解析法 \\
\hline $\begin{array}{l}\text { マイクロマニピュレーショ } \\
\text { ン }\end{array}$ & $\begin{array}{l}\text { マイクロマニピュレーター } \\
\text { (eppendorf 社他) }\end{array}$ & 少数 & 形態, 蛍光 & $\begin{array}{l}\text { デジタル PCR, シングルセ } \\
\text { ルウエスタン, 免疫細胞染色 }\end{array}$ \\
\hline セルソーティング & $\begin{array}{l}\text { セルソーター } \\
\text { (BD 社他) }\end{array}$ & 多数 & 形態, 蛍光 & $\begin{array}{l}\text { デジタル PCR, シングルセ } \\
\text { ルウエスタン, 免疫細胞染色 }\end{array}$ \\
\hline $\begin{array}{l}\text { マイクロラフトコレクティ } \\
\text { ング }\end{array}$ & $\begin{array}{l}\text { QIAscout } \\
\text { (QIAGEN 社) }\end{array}$ & 少数 & なし & $\begin{array}{l}\text { デジタル PCR, シングルセ } \\
\text { ルウエスタン, 免疫細胞染色, } \\
\text { シーケンス }\end{array}$ \\
\hline $\begin{array}{l}\text { レーザーマイクロダイセク } \\
\text { ション }\end{array}$ & LMD7（Leica 社） & 少数 & なし & $\begin{array}{l}\text { デジタル PCR, シングルセ } \\
\text { ルウエスタン, 免疫細胞染色 }\end{array}$ \\
\hline マイクロフルイディクス & $\begin{array}{l}\text { Fluidigm C1 System } \\
\text { (Fluidigm 社) }\end{array}$ & 多数 & なし & シーケンス \\
\hline ドロップレット & $\begin{array}{l}\text { ドロップレット対応装置 } \\
\text { (BioRad 社他) }\end{array}$ & 多数 & なし & デジタル PCR \\
\hline ナノディスペンシング & $\begin{array}{l}\text { ICELL8 Single-Cell System } \\
\text { (WaferGen 社) }\end{array}$ & 最大 1,800 個 & なし & シーケンス \\
\hline
\end{tabular}




\section{2-3. がん幹細胞のモデル細胞}

更に配慮すべき点はどのような細胞をがん幹細胞の候補細胞と同定してシングルセル解析すれば良い かということである。独自に患者の腫瘍を入手できれば良いが，そうでない場合には，株化細胞をシン グルセル解析に用いる必要がある。そこで，一つの候補細胞としてスフェロイド内に出現するがん幹細 胞様細胞が挙げられる。細胞塊からなるスフェロイドは低酸素, 低栄養, 低 $\mathrm{pH}$ などの腫瘍組織で見ら れる微小環境を内包しており，簡便な in vitro 系腫瘍モデルとして非常に有用であり ${ }^{12)}$, 以前から多く の研究で利用されている。著者らは, 神経膠芽腫細胞株（T98G 細胞など）で作製したスフエロイド内 部の低酸素領域に CD133 陽性細胞が出現することを見出した (Fig. 2 ${ }^{13)}$. この細胞はがん幹細胞マー カーであるCD133 の発現が見られるだけでなく, 未分化細胞マーカーであるNestinも発現している. さらに放射線抵抗性, 抗がん剤抵抗性, そして高い遊走性を示す (投稿準備中). 神経膠芽腫がん幹細 胞は放射線抵抗性 ${ }^{14)}$ および抗がん剂抵抗性 ${ }^{15)}$ を示すことが知られている。このスフェロイドを分散し, 単層培養に戻すと CD133 陽性細胞はできなくなる。CD133 発現はスフェロイドという立体構造に依存 した可塑的な現象である点が興味深い。このような性質を示すがん幹細胞様細胞をスフェロイドから単 離し, 分裂後にそれぞれの娘細胞のシングルセル解析を行い, 対称分裂能と非対称分裂能が確認できれ ば，この CD133 陽性細胞をがん幹細胞と同定できる強い根拠が得られる。このようなスフェロイドと いう腫瘍モデル系とシングルセル解析法を用いた実験系を利用すれば，がん幹細胞の実体/実態の解明 に寄与できるのではないだろうか.

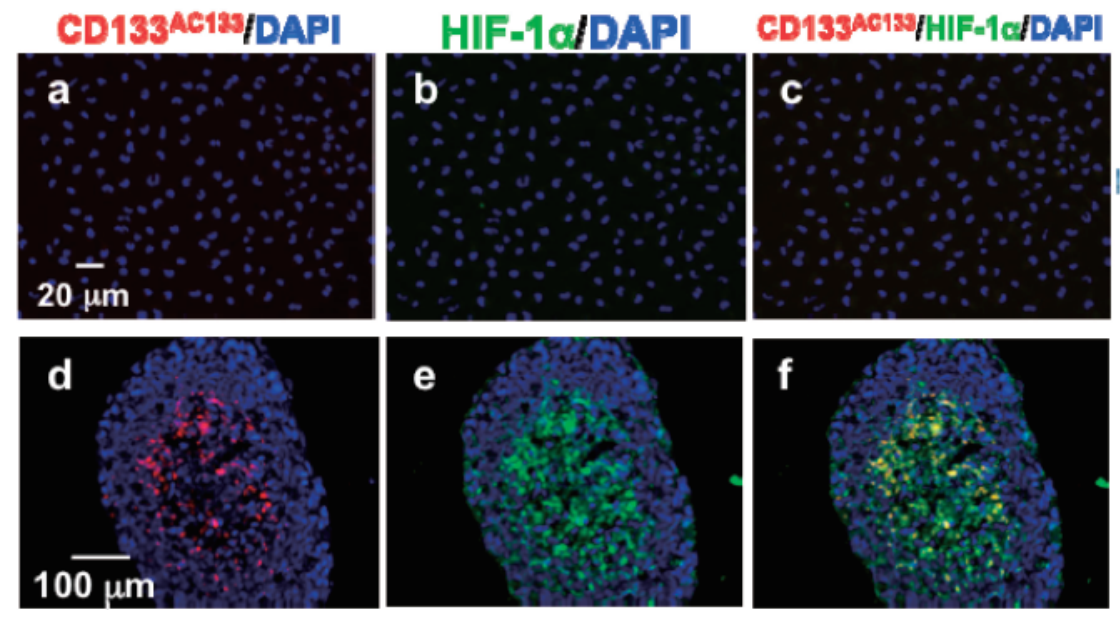

Fig. 2. ヒト神経膠芽腫細胞の CD133AC133/HIF1- $\alpha$ 免疫蛍光 2 重染色像 単層培養細胞 (a-c), スフェロイドの凍結切片 (d-f).

\section{3. がん幹細胞の生存戦略}

がん幹細胞は前述したように腫瘍内の低酸素微小環境に潜伏している。なぜがん幹細胞は低酸素微小 環境を好むのであろうか，低酸素微小環境は，有酸素環境に比べ，活性酸素によるDNA 損傷が少なく， 細胞の生存には有利にはたらく。がん幹細胞はその低酸素微小環境に適応するために次のような適応戦 略を獲得していると考えられる，血管から離れている低酸素微小環境は栄養の供給も受けにくく，がん 細胞のような盛んな増殖を示す細胞の生存には適さない. しかし, そのような環境下でも細胞周期の休 止期に留まり，休眠の状態を維持できれば細胞は長く生存し続けることができる，休眠の誘導には Notch シグナル伝達系が重要な役割を果たしている ${ }^{16)}$ ，低酸素環境下では Notch シグナル伝達系の活性 
化を誘導する HIF-1 $\alpha$ が安定化され, Notch シグナル伝達系が活性化される ${ }^{17)}$ ，さらに低酸素環境下で は内皮細胞から NO が放出され，この NO が Notch シグナル伝達系の活性化に寄与している ${ }^{18)}$. このよ うにがん幹細胞は低酸素微小環境で生存し続けられるよう低酸素で誘導される Notch シグナル伝達系 を巧妙に利用していると考えられる (Fig. 3)。もし放射線照射あるいは抗がん郕投与によって腫瘍細胞 が減少すると, 微小環境の変化によりがん幹細胞は休眠状態から脱し, 活発な非対称分裂を行うことで, 欠損したがん細胞を補い，腫瘍を維持することができる，また，活性酸素によるDNA 損傷が生じたと しても，がん幹細胞は DNA 修復能が充進しているため，身を守ることができる2,19)。このように，が ん幹細胞は, 腫瘍の維持, さらには再発のためにDNA 損傷の蓄積が生じにくい環境で生きていると考 えられる ${ }^{20)}$ ．また，細胞生存シグナル伝達経路の鍵となる Akt の放射線による活性化は，がん細胞より がん幹細胞の方が充進していることが報告されている21).がん幹細胞の Akt を介したシグナル伝達系は DNA 損傷に起因した細胞死が起きにくいようにはたらいているのかもしれない，一方，Aktノックア ウトマウスを用いた実験によると, Akt は細胞内の reactive oxygen species（ROS）の量を高めること， ROS 消去作用を阻害することにより, ROSで誘導される細胞死に寄与していることが示唆されてい る 22 ．従って，放射線による ROS を介した間接的な DNA 損傷で誘導される細胞死への Akt の関与に ついては, 慎重に議論される必要がある。これらに加え, がん幹細胞は免疫作用に対し強い抵抗力を示 すことも報告されている23-25).

\section{4. ハイパーサーミアの標的となるがん幹細胞の生存に寄与する因子}

Fig. 3 に示すように，がん幹細胞の生死に関わる細胞内外の因子をハイパーサーミアにより阻害また は強化することにより，がん幹細胞を標的としたハイパーサーミア効果が期待できる．次にそれぞれの 因子を標的としたハイパーサーミアの有効性について説明する.

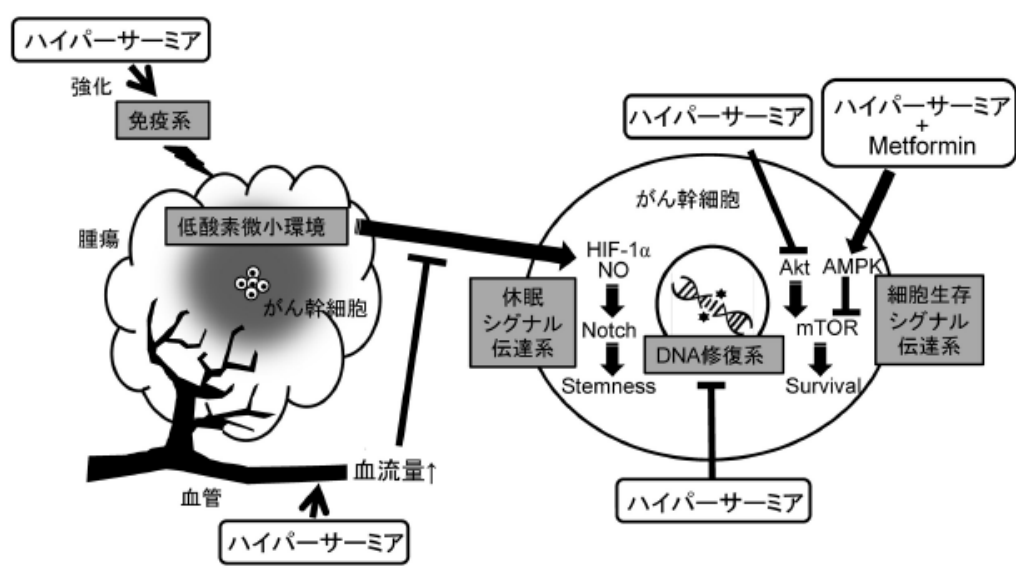

Fig. 3. ハイパーサーミアの標的となるがん幹細胞の 生死に関わる細胞外/内的因子. 


\section{4-1. 細胞外因子}

\section{1 ）低酸素微小環境}

ハイパーサーミアによる腫瘍内血流量の増加はがん幹細胞への酸素供給を高め, HIF-1 $\alpha$ の不安定化 や内皮細胞からの NO 放出量の低下をもたらす可能性がある。このような HIF-1 $\alpha$ の不安定化㧍よび NO放出量の低下は, Notch シグナル伝達系の不活性化を介してがん幹細胞の休眠状態の解除をもたらし, がん幹細胞の形質維持に影響を及ぼすと考えられる。ハイパーサーミアによりマウス腫瘍の低酸素領域 の休眠細胞が減少することが報告されている26)．短絡的にこの休眠状態のがん細胞をがん幹細胞と見な せないが，ハイパーサーミアによりがん幹細胞を休眠状態から細胞分裂期に移行させた後に放射線治療 を行えば，がん幹細胞の放射線増感できる可能性がある。

\section{2 ) 兔疫系}

がん幹細胞は $\mathrm{T}$ 細胞によるアポトーシス誘導などの免疫反応に対し抑制的な作用を示す ${ }^{24)}$. 熱ショッ クタンパク質は免疫系のはたらきを強めることが知られているので, ハイパーサーミアにより熱ショッ クタンパク質を誘導し，この免疫抑制作用を抑えることが期待できる．また腫瘍全体の溶解物で活性化 された樹状細胞を接種したマウスに比べ，がん幹細胞溶解物で活性化された樹状細胞を接種したマウス では, 腫瘍中のがん幹細胞が効果的に排除されたと報告されている ${ }^{27}$. ハイパーサーミアによる熱ショッ クタンパク質誘導で免疫系を強化することにより， がん幹細胞溶解物による樹状細胞の活性化をより高 められる可能性がある.

\section{4-2. 細胞内因子}

\section{1 ) DNA 修復系}

細胞を加温することにより相同組換え修復系の BRCA1/2, RPA, MRN complex ${ }^{28,29)}$, 非相同末端結 合修復系の DNA-PK, Ku70/80 $0^{30,31)}$ および塩基除去修復系の DNA pol. $\beta^{32)}$ など多くの DNA 修復因子 が変性する。このようにハイパーサーミアは異なるタイプの修復系を同時に阻害することが期待でき る33)，そのためがん細胞よりも DNA 修復能が立進しているがん幹細胞に対しては，放射線治療と八イ パーサーミアの併用が非常に有効であると考えられる.

\section{2 ) 細胞生存シグナル伝達系}

細胞生存シグナル伝達経路の鍵となるAktの放射線による活性化は, がん細胞よりがん幹細胞の方 が充進していること，さらにがん幹細胞では八イパーサーミアによる Akt の阻害により放射線増感が 見られることが報告されている ${ }^{21)}$ ．また細胞生存にかかわるその他多数の夕ンパク質, 例えば $\mathrm{Src}$, EGFR, Raf1，HSF1，HIF-1 帛どを同時に阻害することも効果的と考えられる．これらのタンパク質 は Hsp90 のシャペロン機能によって保護されているクライアントプロテインなので, Hsp90 阻害剤を ハイパーサーミアと併用することによりがん幹細胞のハイパーサーミア増感が期待できる。実際に Hsp90 阻害剂（17-allylamino-17-demethoxgeldanamycin,17-AAG）による肝がん幹細胞様細胞の磁気ハ イパーサーミア増感が報告されている34)。 また MCF-7 細胞株と MIA PaCa-2 細胞株において, ハイパー サーミアががん細胞よりもがん幹細胞様細胞でより強く metformin 感受性を増強することが報告されて いる35). ハイパーサーミアと metformin の併用処理が AMPK の活性化を強め mTOR の不活性化をもた らすことが示された，さらに大腸がん細胞株（HCT116 およびSW620）に拈いて，ヘキスト33342色 素に弱蛍光性を示し, がん幹細胞様細胞と見なされる side population（SP）細胞および CD133 陽性細 
胞の割合がマイルドハイパーサーミア $\left(40^{\circ} \mathrm{C}\right)$ によって減少することが報告されている ${ }^{36)}$. これらの細 胞のスフェア形成能や幹細胞マーカー発現率はマイルドハイパーサーミアによって低下した.

\section{5. がん幹細胞に対するナノ粒子を用いたハイパーサーミアの有効性}

近年，がん幹細胞に対するナノ粒子を用いたハイパーサーミアの有效性が注目されている。ナノシェ ルは表面の伝導性金属電子がレーザー光照射で振動することにより熱を発することが知られている。こ のしくみを利用したフォトハイパーサーミアが考案されている。マウス移植乳がん腫瘍を放射線単独処 理あるいはナノシェルハイパーサーミア単独処理した場合は, それぞれ, 乳がん幹細胞の数は減少しな い傾向にあったが, ナノシェルハイパーサーミアを放射線と併用すると, 乳がん幹細胞の致死率を上げ, 腫瘍サイズの著しい縮小がもたらされた ${ }^{37)}$ 。このハイパーサーミアの作用メカニズムについては明らか にされていないが, DNA 修復阻害が要因であろうと推察された ${ }^{38)}$.また aldehyde dehydrogenase (ALDH) 陽性でスフェア形成能を有する MCF-7 細胞の乳がん幹細胞様細胞や HMLER ${ }^{\text {shEcadherin }}$ がん幹細胞は体 外から加温するハイパーサーミアに対して抵抗性を示すが，ナノ粒子を介したフォトハイパーサーミア ではがん幹細胞選択的に感受性が上がることが報告されている ${ }^{39,40)}$. しかしながら，このハイパーサー ミアの作用メカニズムについてもまだよく分かっていない。さらに，A549 抢よび MDA-MB-231 培養 細胞のがん幹細胞様細胞（SP 細胞）に，体外から加温するハイパーサーミアを処理した場合はがん幹 細胞様細胞の割合は減少しなかったが, マグネタイトコアを用いた磁気ハイパーサーミア処理した場合 には，がん細胞に比べてがん幹細胞様細胞に多くのマグネタイトコアが取り込まれ，がん幹細胞様細胞 が選択的に死滅した41). がん幹細胞に対して，より選択的な，より効果的なハイパーサーミアが可能と なれば,がん幹細胞標的治療として大きな期待を寄せることができる。また磁気ハイパーサーミアでは, ネクローシス, 活性酸素種の発生, 遅延性の細胞死なども誘導されるため, その多面的な効果による治 療効果も期待される。このようにがん幹細胞様細胞に対するナノ粒子を用いたハイパーサーミアの有効 性が注目される。しかし, 血管から離れた低酸素領域にナノ粒子を効果的に到達させる方法については, 今後詳しく検討される必要がある。

\section{6. おわりに}

効果的ながん治療を行うためには, 腫瘍内に存在するがん幹細胞の性質を正しく理解し, 効率良く死 滅させる必要がある。しかしながら，がん幹細胞の性質については，まだ不明な点が多く，有効な治療 法はまだ提示されていない，今後，ハイパーサーミアに抏いて本総説で述べたようながん幹細胞の生存 に関わる因子を標的とした分子標的ハイパーサーミア治療の培養細胞レベルおよび移植腫瘍レベルでの 基礎研究が進展し, 新たな治療戦略が開発されることを期待したい.

\section{引用文献}

1) Clarke M.F., Dick J.E., Dirks P.B., Eaves C.J., Jamieson C.H.M., Jones D.L., Visvader J., Weissman I.L., Wahl G.M.: Cancer stem cells-perspectives on current status and future directions: AACR Workshop on cancer stem cells. Cancer Res, 66: 9339-9344, 2006

2) 佐谷秀行, 永野修.: 固形がんのがん幹細胞を標的とした治療戦略の考案. がん分子標的治療, 12: 10-13, 2014.

3) Bar E.E., Lin A., Mahairaki V., Matsui W., Eberhart C.G.: Hypoxia increases the expression of stem-cell markers and promotes clonogenicity in glioblastoma neurospheres. Am J Pathol, 177: 1491-1502, 2010.

4) Iida H., Suzuki M., Goitsuka R.: Hypoxia induces CD133 expression in human lung cancer cells by up-regulation of OCT3/4 
and SOX2. Int J Oncol, 40: 71-79, 2012.

5) Halban P.A., Wollheim C.B., Blondel B., Meda P., Niesor E.N., Mintz D.H.: The possible importance of contact between pancreatic islet cells for the control of insulin release. Endocrinol, 111: 86-94, 1982.

6) Lathia J.D., Hitomi M., Gallagher J., Gadani S.P., Adkins J., Vasanji A., Liu L., Eyler C.E., Heddleston J.M., Wu Q., Minhas S., Soeda A., Hoeppner D.J., Ravin R., McKay R.D., McLendon R.E., Corbeil D., Chenn A., Hjelmeland A.B., Park D.M., Rich J.N.: Distribution of CD133 reveals glioma stem cells self-renew through symmetric and asymmetric cell divisions. Cell Death and Disease, 2: e200, 2011.

7) Navin N., Kendall J., Troge J., Andrews P., Rodgers L., McIndoo J., Cook K., Stepansky A., Levy D., Esposito D., Muthuswamy L., Krasnitz A., McCombie W.R., Hicks J., Wigler M.: Tumor evolution interred by single cell sequencing. Nature, 472: 90-94, 2011.

8) Wang Y., Waters J., Leung M.L., Unruh A., Roh W., Shi X., Chen K., Scheet P., Vattathil S., Liang H., Multani A., Zhang H., Zhao R., Michor F., Meric-Bernstam F., Navin N.E.: Clonal evolution in breast cancer revealed by single nucleus genome sequencing. Nature, 512: 155-160, 2014.

9）鹿島幸恵, 鈴木絢子, 鈴木穣: 一細胞解析技術とその応用. 医学のあゆみ, 258: 269-273, 2016.

10) 荒井文用: 幹細胞研究における一細胞解析. 医学のあゆみ, 258: 293-298, 2016.

11) http://economic.jp/?p=68671

12) Sutherland R.M.: Cell and environment interactions in tumor microregions: The multicell spheroid model. Science, 240 : 177-184, 1988.

13) Ohnishi K., Tani T., Bando S., Kubota N., Fujii Y., Hatano O., Harada H.: Plastic induction of CD133 ${ }^{\text {AC133 }}$-positive cells in the microenvironment of glioblastoma spheroid. Int J Oncol, 45: 581-586, 2014.

14) Bao S., Wu Q., McLendon R.E., Hao Y., Shi Q., Hjelmeland A.B., Dewhirst M.W., Bigner D.D., Rich J.N.: Glioma stem cells promote radioresistance by preferential activation of the DNA damage response. Nature, 444: 756-760, 2006.

15) Dean M., Fojo T., Bates S.: Tumour stem cells and drug resistance. Nat Rev Cancer, 5: 275-284, 2005.

16) Bjornson C.R., Cheung T.H., Liu L., Tripathi P.V., Steeper K.M., Rando T.A.: Notch signaling is necessary to maintain quiescence in adult muscle stem cells. Stem Cells, 30: 232-242, 2012.

17) Quail D.F., Taylor M.J., Postovit L.M.: Microenvironmental regulation of cancer stem cell phenotypes. Curr Stem Cell Res Ther, 7: 197-216, 2012.

18) Charles N., Ozawa T., Squatrito M., Bleau A.M., Brennan C.W., Hambardzumyan D., Holland E.C.: Perivascular nitric oxide activates notch signaling and promotes stem-like character in PDGF-induced glioma cells. Cell Stem Cell, 6: 141-152, 2010.

19) Diehn M., Cho R.W., Lobo N.A., Kalisky T., Dorie M.J., Kulp A.N., Qian D., Lam J.S., Ailles L.E., Wong M., Joshua B., Kaplan M.J., Wapnir I., Dirbas F.M., Somlo G., Garberoglio C., Paz B., Shen J., Lau S.K., Quake S.R., Brown J.M., Weissman I.L., Clarke M.F.: Association of reactive oxygen species levels and radioresistance in cancer stem cells. Nature, 458: 780-783, 2009.

20) Vermeulen L., Sprick M.R., Kemper K., Stassi G., Medema J.P.: Cancer stem cells—old concepts, new insights. Cell Death Different, 15: 947-958, 2008.

21) Man J., Shoemake J.D., Ma T., Rizzo A.E., Godley A.R., Wu Q., Mohammadi A.M., Bao S., Rich J.N., Yu J.S.: Hyperthermia sensitizes glioma stem-like cells to radiation by inhibiting AKT signaling. Cancer Res, 75: 1760-1769, 2015.

22) Nogueira V., Park Y., Chen C.C., Xu P.Z., Chen M.L., Tonic I., Unterman T., Hay N.: Akt determines replicative senescence and oxidative or oncogenic premature senescence and sensitizes cells to oxidative apoptosis. Cancer Cell, 14: 458-470, 2008.

23) Di Tomaso T., Mazzoleni S., Wang E., Sovena G., Clavenna D., Franzin A., Mortini P., Ferrone S., Doglioni C., Marincola F.M., Galli R., Parmiani G., Maccalli C.: Immunobiological characterization of cancer stem cells isolated from glioblastoma patients. Clin Cancer Res, 16: 800-813, 2010.

24) Kawakami Y., Matsushita M., Ueda R., Tsukamoto N., Ohta S.: Immunotherapy targeting cancer stem cells (Japanese). 
Nihon Rinsho Japan J Clin Med 70: 2142-2146, 2012.

25) Wei J., Barr J., Kong L.Y., Wang Y., Wu A., Sharma A.K., Gumin J., Henry V., Colman H., Sawaya R., Lang F.F., Heimberger A.B.: Glioma-associated cancer-initiating cells induce immunosuppression. Clin Cancer Res, 16: 461-473, 2010.

26) Masunaga S., Ono K., Akaboshi M., Nishimura Y., Suzuki M., Kinashi Y., Takagaki M., Hiraoka M., Abe M.: Reduction of hypoxic cells in solid tumours induced by mild hyperthermia: special reference to differences in changes in the hypoxic fraction between total and quiescent cell populations. Br J Cancer, 76: 588-593, 1997.

27) Ning N., Pan Q., Zheng F., Teitz-Tennenbaum S., Egenti M., Yet J., Li M., Ginestier C., Wicha M.S., Moyer J.S., Prince M.E., Xu Y., Zhang X.L., Huang S., Chang A.E., Li Q.: Cancer stem cell vaccination confers significant antitumor immunity. Cancer Res, 72: 1853-1864, 2012.

28) Eppink B., Krawczyk P.M., Stap J., Kanaar R.: Hyperthermia-induced DNA repair deficiency suggests novel therapeutic anti-cancer strategies. Int J Hypertherm, 28: 509-517, 2012.

29) Krawczyk P.M., Eppink B., Essers J., Stap J., Rodermond H., Odijk H., Zelensky A., van Bree C., Stalpers L.J., Buist M.R., Soullié T., Rens J., Verhagen H.J., O’Connor M.J., Franken N.A., Ten Hagen T.L., Kanaar R., Aten J.A.: Mild hyperthermia inhibits homologous recombination, induces BRCA2 degradation, and sensitizes cancer cells to poly (ADP-ribose) polymerase-1 inhibition. Proc Natl Acad Sci USA, 108: 9851-9856, 2011.

30) Matsumoto Y., Suzuki N., Sakai K., Morimatsu A., Hirano K., Murofushi H.: A possible mechanism for hyperthermic radiosensitization mediated through hyperthermic lability of $\mathrm{Ku}$ subunits in DNA-dependent protein kinase. Biochem Biophys Res Commun, 234: 568-572, 1997.

31) Ihara M., Takeshita S., Okaichi K., Okumura Y., Ohnishi T.: Heat exposure enhances radiosensitivity by depressing DNA-PK kinase activity during double strand break repair. Int J Hypertherm, 30: 102-109, 2014.

32) Kampinga H.H., Dynlacht J.R., Dikomey E.: Mechanism of radiosensitization by hyperthermia ( $>$ or $=43$ degrees C) as derived from studies with DNA repair defective mutant cell lines. Int J Hypertherm, 20: 131-139, 2004.

33) Oei A.L., Vriend L.E.M., Crezee J., Franken N.A.P., Krawczyk P.M.: Effects of hyperthermia on DNA repair pathways: one treatment to inhibit them all. Radiat Oncol, 10:165, 2015.

34) Yang R., Tang Q., Miao F., An Y., Li M., Han Y., Wang X., Wang J., Liu P., Chen R.: Inhibition of heat-shock protein 90 sensitizes liver cancer stem-like cells to magnetic hyperthermia and enhances anti-tumor effect on hepatocellular carcinomaburdened nude mice. Int J Nanomed, 10: 7345-7358, 2015.

35) Lee H., Park H.J., Park C.S., Oh E.T., Choi B.H., Williams B., Lee C.K., Song C.W.: Response of breast cancer cells and cancer stem cells to metformin and hyperthermia alone or combined. PLoS One 9: e87979, 2014.

36) Gao F., Ye Y., Zhang Y., Yang J.: Water bath hyperthermia reduces stemness of colon cancer cells. Clin Biochem, 46:17471750,2013

37) Atkinson R.L., Zhang M., Diagaradjane P., Peddibhotla S., Contreras A., Hilsenbeck S.G., Woodward W.A., Krishnan S., Chang J.C., Rosen J.M.: Thermal enhancement with optically activated gold nanoshells sensitizes breast cancer stem cells to radiation therapy. Sci Transl Med, 2: 55ra79, 2010.

38) Pelicci P.G., Dalton P., Orecchia R.: Heating cancer stem cells to reduce tumor relapse. Breast Cancer Res, 13: 305, 2011.

39) Burke A.R., Singh R.N., Carroll D.L., Wood J.C., D’Agostino R.B. Jr, Ajayan P.M., Torti F.M., Torti S.V.: The resistance of breast cancer stem cells to conventional hyperthermia and their sensitivity to nanoparticle-mediated photothermal therapy. Biomaterials, 33: 2961-2970, 2012.

40) Xu Y., Wang J., Li X., Liu Y., Dai L., Wu X., Chen C.: Selective inhibition of breast cancer stem cells by gold nanorods mediated plasmonic hyperthermia. Biomaterials. 35: 4667-4677, 2014.

41) Sadhukha T., Niu L., Wiedmann T.S., Panyam J.: Effective elimination of cancer stem cells by magnetic hyperthermia. Mol Pharm, 10: 1432-1441, 2013. 